\title{
Late Quaternary Geology of Nain Bay, Labrador
}

DAVID J.W. PIPER, DARYL M. WIGHTMAN, JOHN F. LEWIS and GREG J.T. DWYER Departments of Geology and Oceanography, Dalhousie University, Halifax, Nova Scotia

\section{Introduction}

Nain Bay (Fig. 1) is a long fjord on the central coast of Labrador. The bordering mountains reach heights of 400 to $600 \mathrm{~m}$. The Fraser River drains to the head of the Bay. Water depths in the Bay reach $132 \mathrm{~m}$ south of Rhodes Island; there is a $18 \mathrm{~m}$ deep sill at Strathcona Run. Local bedrock comprises the Nain anorthosites intruded into basement complex gneisses (Wheeler, 1960). The bedrock has been scraped bare by the Wisconsin glaciation, and there appears to be little till. The land is still rising isostatically at around $30 \mathrm{~cm}$ per century (Andrews, 1970), following deglaciation some 14,000 years ago (Prest, 1970), and raised beaches are common.

\section{Seismic Reflection Profile}

A transparent seismic stratigraphic unit with rare strong reflectors is recognisable above acoustic basement (Fig. 2). The unit fills irregularities in the basement surface, and has a maximum thickness of about 0.25 secs. (2 way travel time). The unit is interpreted as Holocene marine silty mud, with silt or sand layers. Acoustic basement appears to be bedrock, at least in most places.

\section{Surficial Sediment Distribution}

The Fraser River flows out of Tasisuak Lake through a series of rapids, and terminates in a delta. Nain Bay east of the delta, as far as Cape Williams, is floored with silty muds, showing good penetration and weak sub-bottom reflectors on the echo-sounder (Kelvin-Hughes MS 26B) profiles. There is a shallow sill just south east of Cape Williams.
East of here, sediment distribution is much more irregular, and most of the bottom appears from the MS26B profiles to be strongly reflective: most probably sand or muddy sand. There appears to be a little mud in the deeper basins. I grab sample near core 3 comprises sandy mud; and the deepest areas south of Rhodes Island $(\sim 90 \mathrm{~m})$ showed some sub-bottom penetration with the MS26B.

In Tikkoatokak Bay, rather poor MS $26 \mathrm{~B}$ profiles suggest penetrable muds north-west of ukpaume Island and reflective sands to the south-east.

Cores 4,5 , and $6(42,55 \& 83 \mathrm{~cm}$ long respectively) were taken from the silty muds. The sediment is light olive grey $(5 Y 5 / 2)$, faintly laminated, and of rather uniform grain size distribution ( 3 to $15 \%$ sand; 45 to $70 \%$ silt; 20 to $50 \%$ clay; median diameter around $6 \emptyset$ ). The muds contain rare occurrences of pebbles, presumably ice-rafted.

Short cores (numbers 1,2 , and 3) and grab samples from the sands recovered medium and fine sand and muddy sand. Sand petrology is similar to that observed by slatt and Lew (1973) for sediments immediately offshore on the Labrador Shelf. The dominant heavy minerals are (in order of abundance) biotite, hornblende, clinopyroxene, hypersthene, garnet and rutile. The sand fraction of the silty muds from the upper part of Nain Bay was of similar petrology.

Discussion

Since the area is undergoing rapid uplift, the sands in the outer part of the Bay are presumably not relict sediments, but in equilibrium with

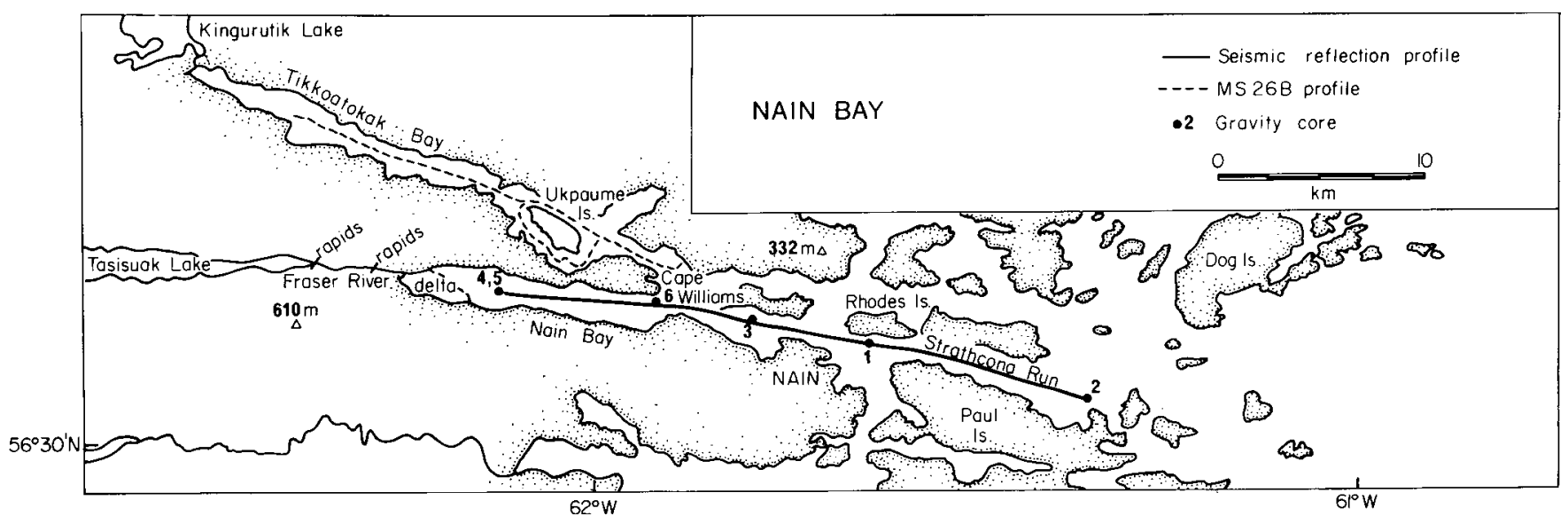

Fig. 1. General map of Nain Bay, showing location of data. 


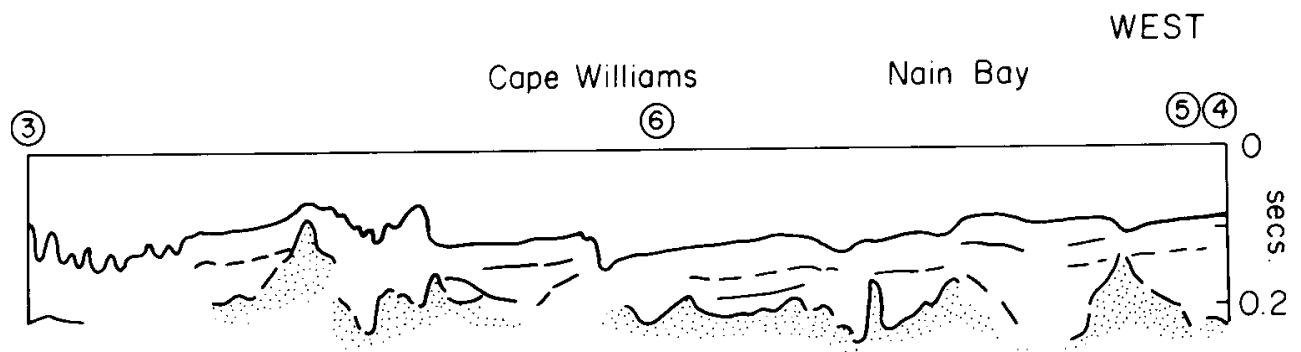

Rhodes Island

(1)

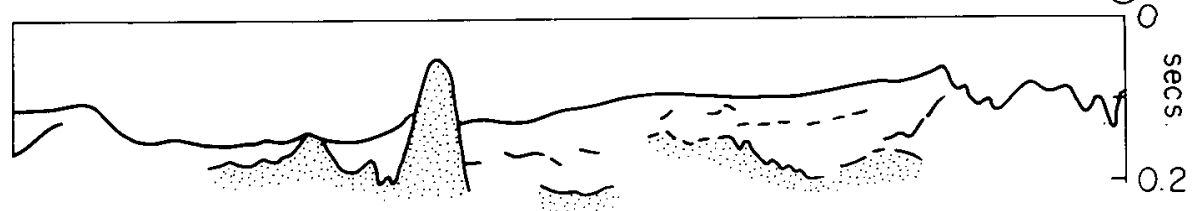

EAST

(2)

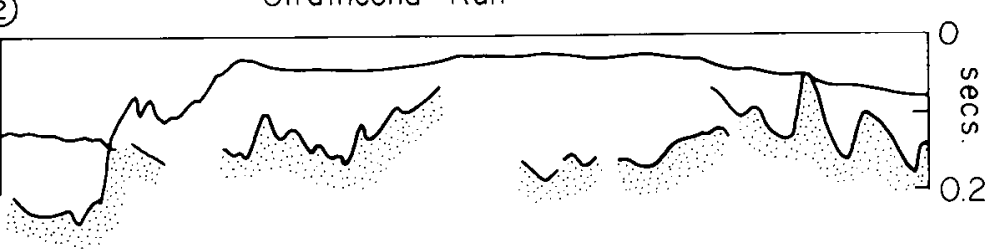

Fig. 2. Line drawing of seismic reflection profiles, Nain Bay. Numbers in circles are gravity core locations.

modern transporting agents. Tidal currents are probably more effective than waves in moving sediment. Currents of up to $.5 \mathrm{knot}(26 \mathrm{~cm} / \mathrm{s})$ were measured at 30-m depth off Cape williams, and tidal currents of up to 2 knots $(104 \mathrm{~cm} / \mathrm{s})$ are developed south of Rhodes Island (Anon, 1965; CHS chart 4748). These currents appear to be transporting shelf sands into the fjord.

Coarse sediment from the Fraser River is trapped in Tasisuak Lake, or deposited on the delta, and silts of fluvial origin are accumulating in the head of Nain Bay west of Cape Williams.

In the past when the water depth in the fjord was greater, muds of fluvial and glacial outwash origin accumulated in the deep water the whole length of the fjord. Only as the land rose was it possible to bring in significant amounts of sand from the shelf.

\section{Acknowledgements}

We thank the Master, officers and crew of C.S.S. Hudson; Car1 M. Boyd, senior scientist of cruise 73-031; and several colleagues who have worked with us on this data in class projects.

\section{References}

ANDREWS, J.T., 1970, A geomorphological study of post-glacial uplift with particular reference to Arctic Canada. London:Institute of Geographers, $156 \mathrm{p}$.

ANON, 1965, Labrador and Hudson Bay Pilot. Canadian Hydrographic Service, 552 p.

PREST, V.K., 1970, Quaternary Geology, In Douglas, R.J.W., Geology and Economic Minerals of Canada, Dept. of Energy, Mines and Resources, Economic Geology Report No. 1.

SLATT, R.M., and LEW, A.E., 1973, Provenance of Quaternary Sediments on the Labrador Continental Shelf and Slope, J. Sedim. Petrol., 43, pp. 1054-1060.

WHEELER, E.P. 2nd, 1960, Anorthosite-adamellite complex of Nain, Labrador, Geol. Soc. Amer. Bull., 71, pp. 1755-1762. 